\title{
Role of magnetic resonance in cardiology
}

\section{(i) Vesna Pehar- \\ Pejčinović*, (i) Viktor Peršić}

Clinic for treatment, rehabilitation and prevention of cardiovascular diseases, Thalassoterapia Opatija, Opatija, Croatia
RECEIVED:

October 25, 2018

ACCEPTED:

November 5, 2018

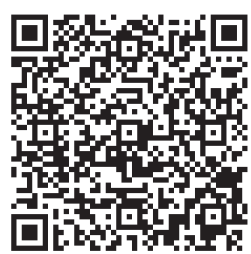

KEYWORDS: cardiovascular magnetic resonance, guidelines. CITATION: Cardiol Croat. 2018;13(11-12):413. | https://doi.org/10.15836/ccar2018.413

*ADDRESS FOR CORRESPONDENCE: Vesna Pehar-Pejčinović, Thalassotherapia Opatija Klinika za liječenje rehabilitaciju i prevenciju kardiovaskularnih bolesti, M. Tita 188, HR-51410 Opatija, Croatia. / Phone: +385-91-8970-280 / E-mail: pehar.vesna@gmail.com

ORCID: Vesna Pehar-Pejčinović, https://orcid.org/0000-0002-8921-7999 • Viktor Peršić, https://orcid.org/0000-0003-4473-5431

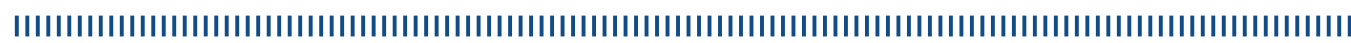

The most frequent indications for cardiovascular magnetic resonance (CMR) are inflammatory and ischemic heart diseases and cardiomyopathies. ${ }^{1}$ It is also very useful in imaging of congenital heart disease. CMR provides detailed information about cardiovascular anatomy and function and particularly in characterization of the myocardial tissue including the detection of edema and fibrosis. MRI is also used in evaluation of coronary disease and myocardial perfusion. Because of mentioned fourteen of the 26 ESC guidelines (53.8\%) contain specific recommendations regarding the use of CMR. 